\title{
STUDI FAAL PARU DAN FAKTOR DETERMINANNYA PADA PEKERJA DI INDUSTRI SAWMILL
}

\author{
STUDY OF LUNG FUNCTION AND THE DETERMINANT FACTORS ON \\ WORKERS IN SAWMILL INDUSTRY
}

\author{
Ulfa Hikmayanti \\ PT. Multibrata Anugrah Utama \\ E-mail: ulfahikmayanti@gmail.com
}

\begin{abstract}
Sawmill industry processes log into sawmill and also results wood dust as by-product. Dust can be potentially inhaled by workers and cause impaired lung function. In addition, several other factors can effect lung function such as age, body mass index status, smoking habit and using respiratory protective equipment habits. The purpose of this study was to describe lung function on workers in sawmill industry and the determinant factors. This research was an observational type with descriptive method. This study used total population with 36 workers. The data were obtained from interview, dust measurement, body mass index measurement and lung function test, meanwhile the instruments were questionnaire, high volume dust sampler (hvds), microtoise, weight scale and spirometer. This data were analyzed by cross tabulation. The results of this study showed that the time weighted average concentration in UD. Sinar Abadi was $1.59 \mathrm{mg} / \mathrm{m}^{3}$, meanwhile spirometry test showed $42.8 \%$ had normal lung function and $52.8 \%$ had impaired lung function. Workers who had impaired lung function were $64.7 \%$ exposed to doses $>5 \mathrm{mg} / \mathrm{m}^{3}$.tahun, $60 \%$ were $>44$ years old, $100 \%$ were obese, $69.9 \%$ were smoker and $76.5 \%$ never used respiratory protective equipment. The time weighted average concentration was above from threshold limit value and most of the workers had impaired lung function. Workers with impaired lung function are more likely to be exposed to dose $>5 \mathrm{mg} / \mathrm{m}^{3}$.years, older, obese, smoker, and didn't use respiratory protective equipment.
\end{abstract}

Keywords: determinant factors, lung function, wood dust

\begin{abstract}
ABSTRAK
Industri sawmill mengolah kayu gelondongan menjadi kayu gergajian dan juga menghasilkan produk samping berupa debu kayu. Debu berpotensi terhirup oleh pekerja dan mengakibatkan gangguan faal paru. Selain debu, beberapa faktor lain yang dapat memengaruhi faal paru diantaranya umur, status indeks massa tubuh, gangguan pada pernapasan, kebiasaan merokok dan kebiasaan menggunakan alat pelindung pernapasan. Tujuan penelitian ini untuk mendeskripsikan faal paru pekerja di industri sawmill dan faktor determinannya. Jenis penelitian ini adalah observasional dengan metode deskriptif. Penelitian ini menggunakan total populasi yang berjumlah 36 pekerja. Data didapatkan dari wawancara pekerja, pengukuran debu, pengukuran status indeks massa tubuh dan pemeriksaan faal paru, sedangkan alat dan instrumen yang digunakan adalah lembar kuesioner, high volume dust sampler (hvds), microtoise, timbangan berat badan dan spirometer. Data dianalisis dengan tabulasi silang. Hasil pengukuran kadar rata-rata pembebanan waktu di UD. Sinar Abadi adalah 1,59 mg/m sedangkan hasil pemeriksaan spirometri menunjukkan sebesar $42,8 \%$ memiliki faal paru normal dan 52,8\% memiliki gangguan faal paru. Pekerja yang memiliki gangguan faal paru diantaranya $64,7 \%$ terpapar dosis $>5 \mathrm{mg} / \mathrm{m}^{3}$.tahun, $60 \%$ berumur $>44$ tahun, $100 \%$ obesitas, $69,9 \%$ merupakan perokok dan $76,5 \%$ tidak pernah menggunakan alat pelindung pernapasan. Kadar Rata-rata pembebanan waktu berada di atas nilai ambang batas dan sebagian besar pekerja mengalami gangguan faal paru. Pekerja yang mengalami gangguan faal paru cenderung dialami oleh pekerja yang terpapar dosis $>5 \mathrm{mg} /$ $\mathrm{m}^{3}$.tahun, berumur lebih tua, obesitas, seorang perokok serta tidak pernah menggunakan alat pelindung pernapasan.
\end{abstract}

Kata kunci: debu kayu, faal paru, faktor determinan

\section{PENDAHULUAN}

Industri kayu merupakan industri yang mengolah kayu menjadi berbagai macam produk, salah satunya adalah sawmill dan dalam pengolahannya juga menghasilkan produk samping

berupa debu kayu di tempat kerja (NCDOL, 2012). Pekerja di industri kayu berpotensi terpapar debu kayu dan dosis paparan yang diterima setiap pekerja dapat berbeda- beda. Dosis paparan merupakan 
hasil kali kadar beserta lama paparan yang dapat memengaruhi respons tubuh seseorang terhadap debu (Lu, 2006). Tinggi rendahnya kadar debu kayu di tempat kerja maupun paparan nya terhadap pekerja dapat tergantung pada alat yang digunakan, jenis kayu, ventilasi umum dan penggunaan alat pelindung pernapasan yang digunakan (IARC, 2012). Berdasarkan hasil pengukuran yang dilakukan di 25 negara bagian Eropa, kadar debu kayu inhalabel ditemukan mulai dari, di bawah $0,5 \mathrm{mg} / \mathrm{m}^{3}$, $0,5-1 \mathrm{mg} / \mathrm{m}^{3}, 1-2 \mathrm{mg} / \mathrm{m}^{3}, 2-5 \mathrm{mg} / \mathrm{m}^{3}$, hingga melebihi $5 \mathrm{mg} / \mathrm{m}^{3}$. Sedangkan distribusi pekerja yang terpapar kadar tersebut secara berurutan adalah $21 \%, 17 \%$, $21 \%, 25 \%$ dan $16 \%$. Hal ini menunjukkan bahwa kadar debu kayu pada setiap industri berbeda- beda (Kauppinen, dkk., 2006).

Debu kayu merupakan debu non fibrogenik yang menyebabkan meningkatnya sekresi mukus dan perubahan obstruksi pada fungsi paru. Perubahan ini berupa sedikit penurunan $\mathrm{FEV}_{1}$ dan sedikit pada VC (Suyono, 1995). Hal ini ditunjukkan pada penelitian yang dilakukan oleh Ennin, dkk. (2015) bahwa sebanyak 34 pekerja (37\%) mengalami gangguan obstruksi dan sebanyak 29 pekerja (32\%) mengalami gangguan restriksi. Hasil penelitian tersebut menunjukkan adanya penurunan $\mathrm{FEV}_{1}$ yang signifikan pada pekerja pengolahan kayu (operator sawmill, tukang kayu, penjual kayu dan buruh kayu) dibandingkan dengan kelompok kontrol. Sejalan dengan penelitian yang dilakukan oleh Schlünssen, dkk. (2002) yang menunjukkan adanya penurunan $\mathrm{FEV}_{1}$ yang signifikan pada pekerja pengolahan kayu dibandingkan dengan kelompok kontrol. Hal ini menunjukkan bahwa debu kayu dapat menyebabkan penurunan fungsi paru, terutama pada forced expiratory volume/volume ekspiratori paksa.

Penurunan fungsi paru dapat disebabkan oleh dosis paparan yakni kadar debu beserta lama paparan yang diterima pekerja. Semakin tinggi dosis yang diterima, maka semakin berisiko pula pekerja mengalami penurunan fungsi paru ( $\mathrm{Lu}, 2006)$. Selain dosis paparan, penurunan faal paru juga dapat disebabkan oleh beberapa faktor lain yang bukan berasal dari pekerjaan diantaranya umur, status indeks massa tubuh, kebiasaan merokok (Aw, dkk, 2007) dan kebiasaan menggunakan alat pelindung pernapasan untuk melindungi pernapasan dari debu kayu saat bekerja (Soeripto, 2008).

Untuk mengetahui kondisi kesehatan pekerja secara berkala dan mencegah gangguan paru berkembang menjadi penyakit yang berat, maka perlu dilakukan deteksi dini (Suma'mur, 2009).
Deteksi dini pada pernapasan dapat dilakukan melalui spirometri. Spirometri merupakan jenis tes yang sering digunakan untuk mengevaluasi kesehatan pernapasan pekerja. Pemeriksaan ini berguna untuk pengambilan keputusan penempatan pekerja sebelum bekerja, penggunaan alat pelindung pernapasan dan untuk menilai adanya hubungan antara paparan dan efek terhadap kesehatan (OSHA, 2013). Manfaat spirometri adalah untuk mengevaluasi gejala dan tanda penyakit paru seperti sesak napas dan batuk, serta menilai dan memantau kondisi kesehatan pekerja yang berisiko mengalami gangguan paru akibat terpapar debu di lingkungan kerja. (ATS, 2005). Untuk mendeteksi adanya gangguan, alat ini bekerja dengan mengukur kapasitas vital paksa dan volume ekspirasi paksa pada detik pertama (OSHA, 2013).

Industri sawmill merupakan industri yang mengolah kayu gelondongan menjadi produk sawmill atau kayu gergaji. Proses sawmill menggunakan alat yang dinamakan band saw. Kayu diolah sesuai dengan ukuran yang diinginkan. Pemotongan log kayu menggunakan alat band saw untuk dijadikan produk sawmill, menghasilkan produk samping berupa debu kayu. Pekerja pengoperasian band saw tersebut berpotensi terpapar debu kayu melalui di tempat kerja.

Kadar debu di industri sawmill perlu diukur untuk mengetahui seberapa besar kadar debu di udara, sedangkan untuk mengetahui kondisi paru-paru pekerja yang terpapar debu kayu dapat dilakukan pemeriksaan faal paru menggunakan alat spirometer. Hasil pengukuran debu di lingkungan kerja dan faal paru tersebut dapat dijadikan bahan pertimbangan untuk tindakan pengendalian. Tujuan penelitian ini adalah untuk mendeskripsikan faal paru pada pekerja di industri sawmill dan faktor yang determinan nya.

\section{METODE}

Berdasarkan teknik pengambilan data, penelitian ini merupakan observasional dengan metode yang digunakan adalah deskriptif. Penelitian ini menggunakan total populasi yang berjumlah 36 pekerja. Penelitian ini dilaksanakan pada bulan Desember 2016 sampai Juli 2017 bertempat di UD. Sinar Abadi. Variabel dependen yang diteliti adalah faal paru, sedangkan variabel independen yang diteliti diantaranya dosis paparan, umur, status indeks massa tubuh (IMT), kebiasaan merokok dan kebiasaan menggunakan alat pelindung pernapasan. 
Pengumpulan data dilakukan melalui wawancara dengan responden terkait umur, lama kerja, kebiasaan merokok dan kebiasaan menggunakan alat pelindung pernapasan, pengukuran kadar debu, status indeks massa tubuh dan faal paru, sedangkan alat yang digunakan adalah high volume dust sampler ( $h v d s)$, microtoise, timbangan berat badan dan lembar kuesioner. Hasil tes faal paru dikelompokkan berdasarkan pedoman GOLD (2010), hasil pengukuran status indeks massa tubuh dikelompokkan berdasarkan WHO (2004), sedangkan pengategorian kebiasaan merokok berdasarkan Kang, dkk (2003). Data yang telah dikumpulkan disajikan dalam bentuk tabel distribusi dan narasi yang selanjutnya dianalisis menggunakan tabulasi silang dan dinarasikan.

\section{HASIL}

\section{Faal Paru}

Faal paru pekerja diukur menggunakan alat spirometer dengan parameter $\mathrm{FEV}_{1}$ dan $\mathrm{FVC}$, dinyatakan dalam \% predictive. Nilai $\mathrm{FEV}_{1}<$ $80 \%$ predictive, maka pekerja tersebut mengalami gangguan obstruksi, jika nilai $\mathrm{FVC}<80 \%$ predictive maka pekerja tersebut mengalami gangguan restriksi (GOLD, 2010). Distribusi pekerja berdasar nilai FEV1 dan FVC pada tabel 1.

Tabel 1. Distribusi Pekerja Berdasarkan Nilai FEV dan FVC di Industri Sawmill Tahun 2017

\begin{tabular}{lcc}
\hline \multicolumn{1}{c}{ Statistik } & $\begin{array}{c}\text { FVC } \\
\text { (\% pred.) }\end{array}$ & $\begin{array}{c}\text { FEV }_{\mathbf{1}} \\
(\boldsymbol{\%} \text { pred. })\end{array}$ \\
\hline Rata-rata & 78,33 & 85,67 \\
Standar Deviasi & 12,017 & 12,435 \\
Nilai Minimum & 56 & 63 \\
Nilai Maksimum & 102 & 106 \\
\hline Modus & 81 & 83 \\
\hline Median & 80,50 & 85 \\
\hline
\end{tabular}

Tabel 2. Distribusi Pekerja Berdasarkan Status Faal Paru di Industri Sawmill Tahun 2017

\begin{tabular}{lcc}
\hline Status Faal Paru & Frekuensi (n) & $\begin{array}{c}\text { Persentase } \\
\text { (\%) }\end{array}$ \\
\hline Normal & 17 & 47,2 \\
Tidak Normal & 19 & 52,8 \\
\hline
\end{tabular}

Rata-rata nilai FVC pekerja di industri sawmill adalah 78,33 $\pm 12,017$ dengan nilai terendah sebesar $56 \%$ predictive dan paling tinggi adalah $102 \%$ predictive. Nilai FVC yang paling banyak adalah $81 \%$ predictive dengan nilai tengah yakni $80,50 \%$ predictive. Rata-rata nilai $\mathrm{FEV}_{1}$ adalah $85,67 \pm$ 12,435 dengan nilai paling rendah sebesar $63 \%$ predictive dan nilai paling tinggi adalah $106 \%$ predictive. Nilai $\mathrm{FEV}_{1}$ yang paling banyak keluar adalah $83 \%$ predictive dengan nilai tengahnya adalah $85 \%$ predictive.

Tabel 2 menunjukkan bahwa sebanyak 47,2\% pekerja di industri sawmill tidak memiliki gangguan faal paru dan sebanyak $52,8 \%$ pekerja memiliki gangguan faal paru. Dari 19 pekerja yang mengalami gangguan faal paru, dapat dibedakan berdasarkan jenis dan derajat gangguan faal paru.

Dari Tabel 3 diketahui bahwa terdapat 42,1\% pekerja mengalami gangguan faal paru restriksi, $10,5 \%$ pekerja mengalami gangguan faal paru obstruksi dan $47,4 \%$ pekerja mengalami gangguan faal paru campuran. Selanjutnya, dari status faal paru juga dapat diketahui derajat gangguan faal paru yang disajikan dalam Tabel 4.

Dari Tabel 4 diketahui bahwa terdapat $42,1 \%$ pekerja mengalami gangguan faal paru restriksi. $10,5 \%$ pekerja mengalami gangguan faal paru obstruksi.

Tabel 3. Distribusi Pekerja Berdasarkan Jenis Gangguan Faal Paru Pekerja di Industri Sawmill Tahun 2017

\begin{tabular}{lcc}
\hline $\begin{array}{l}\text { Jenis Gangguan } \\
\text { Faal Paru }\end{array}$ & Frekuensi (n) & $\begin{array}{c}\text { Persentase } \\
(\mathbf{\%})\end{array}$ \\
\hline Restriksi & 8 & 42,1 \\
Obstruksi & 2 & 10,5 \\
Campuran & 9 & 47,4 \\
\hline Total & 19 & 100,0 \\
\hline
\end{tabular}

Tabel 4. Distribusi Pekerja Berdasarkan Derajat Gangguan Faal Paru di Industri Sawmill Tahun 2017

\begin{tabular}{lcc}
\hline $\begin{array}{l}\text { Derajat Gangguan } \\
\text { Faal Paru }\end{array}$ & Frekuensi (n) & $\begin{array}{c}\text { Persentase } \\
(\mathbf{\%})\end{array}$ \\
\hline Restriksi ringan & 8 & 42,1 \\
Obstruksi ringan & 2 & 10,5 \\
\hline Total & 10 & 100,0 \\
\hline
\end{tabular}


Tabel 5. Hasil Pengukuran Kadar Debu di Industri Sawmill Tahun 2017

\begin{tabular}{lc}
\hline Waktu (jam) & Kadar debu $\left(\mathbf{m g} / \mathbf{m}^{\mathbf{3}}\right)$ \\
\hline $08.00-12.00$ & 2,34 \\
$12.00-13.00$ (waktu istirahat) & 0,58 \\
$13.00-14.30$ & 1,47 \\
$14.30-16.00$ & 1,97 \\
\hline Rata-rata & 1,59 \\
\hline
\end{tabular}

\section{Kadar Debu}

Hasil pengukuran kadar debu yang dilakukan pada pagi hari adalah $2,34 \mathrm{mg} / \mathrm{m}^{3}$, pada waktu istirahat sebesar $0,58 \mathrm{mg} / \mathrm{m}^{3}$, saat siang hari sebesar $1,47 \mathrm{mg} / \mathrm{m}^{3}$ dan pada saat sore hari adalah 1,97 $\mathrm{mg} / \mathrm{m}^{3}$. Pengukuran kadar debu yang dilakukan pada waktu pagi, waktu istirahat, siang dan sore hari ditujukan untuk menghitung kadar Rata-rata waktu tertimbang selama 8 jam kerja sehari. Hasil kadar rata-rata waktu tertimbang adalah $1,59 \mathrm{mg} /$ $\mathrm{m}^{3}$. Kadar debu di udara selama 8 jam kerja dalam sehari tersebut dapat naik maupun turun atau bersifat fluktatif. Hasil pengukuran kadar debu yang diukur sebanyak 4 titik menunjukkan adanya fluktuasi. Tabel 5 menunjukkan kadar debu yang tinggi pada saat pagi hari $\left(2,34 \mathrm{mg} / \mathrm{m}^{3}\right)$ dan kadar debu paling rendah pada waktu istirahat $\left(0,58 \mathrm{mg} / \mathrm{m}^{3}\right)$.

\section{Dosis Paparan}

Tabel 6 menunjukkan bahwa mayoritas dosis paparan yang diterima pekerja di industri sawmill berada pada rentang $0,5-10 \mathrm{mg} / \mathrm{m}^{3}$.tahun $(69,4 \%)$ dengan dosis paparan terendah adalah $0,52 \mathrm{mg} /$ m3.tahun dan tertinggi adalah $39,75 \mathrm{mg} / \mathrm{m}^{3}$.tahun. Rata-rata dosis paparan yang diterima pekerja adalah $8,24 \pm 9,3$ dengan rata-rata dosis paparan terbanyak adalah $4,77 \mathrm{mg} / \mathrm{m}^{3}$.tahun dan nilai tengah sebesar $4,77 \mathrm{mg} / \mathrm{m}^{3}$.tahun.

Tabel 6. Distribusi Pekerja Berdasarkan Dosis Paparan di Industri Sawmill Tahun 2017

\begin{tabular}{lcc}
\hline $\begin{array}{c}\text { Dosis Paparan } \\
\left(\mathbf{m g} / \mathbf{m}^{3} \cdot \text { tahun }\right)\end{array}$ & Frekuensi (n) & Persentase (\%) \\
\hline $0,5-10$ & 25 & 69,4 \\
$10,5-20$ & 7 & 16,7 \\
$20,5-30$ & 2 & 5,6 \\
$30,5-40$ & 2 & 5,6 \\
\hline Total & 36 & 100,0 \\
\hline
\end{tabular}

\section{Karakteristik Individu}

\section{Umur}

Tabel 7 menunjukkan pekerja yang bekerja di industri sawmill terdiri dari berbagai golongan umur. Mayoritas pekerja berada pada rentang umur $37-47$ tahun (25\%) dan 48-58 tahun (25\%), dengan umur paling muda adalah 17 tahun dan yang paling tua adalah 62 tahun. Rata-rata pekerja di industri sawmill berumur $38,56 \pm 12,63$, umur terbanyak adalah 22 tahun dan 44 tahun dengan nilai tengah umur pekerja berada pada nilai 44 tahun.

\section{Status Indeks Massa Tubuh (IMT)}

Berdasarkan Tabel 8 diketahui mayoritas indeks massa tubuh pekerja di industri sawmill berada pada kategori normal $(55,6 \%)$ dengan status indeks massa tubuh pekerja yang paling kurus sebesar $14,69 \mathrm{~kg} /$ $\mathrm{m}^{2}$ dan paling besar adalah $30,78 \mathrm{~kg} / \mathrm{m}^{2}$. Rata-rata status indeks massa tubuh pekerja adalah 21,44 \pm 3,99 dengan nilai tengah $21,08 \mathrm{~kg} / \mathrm{m}^{2}$.

\section{Kebiasaan Merokok}

Berdasarkan Tabel 9 diketahui bahwa mayoritas pekerja di industri sawmill adalah seorang perokok yakni sebesar $63,9 \%$. Selain itu terdapat mantan

Tabel 7. Distribusi Umur Responden di Industri Sawmill Tahun 2017

\begin{tabular}{lcc}
\hline Umur (tahun) & Frekuensi (n) & Persentase (\%) \\
\hline $15-25$ & 8 & 22,2 \\
$26-36$ & 8 & 22,2 \\
$37-47$ & 9 & 25,0 \\
$48-58$ & 9 & 25,0 \\
$59-69$ & 2 & 5,6 \\
\hline Total & 36 & 100,0 \\
\hline
\end{tabular}

Tabel 8. Distribusi Status Indeks Massa Tubuh (IMT) Responden di Industri Sawmill Tahun 2017

\begin{tabular}{lcc}
\hline Status IMT $\left(\mathbf{k g} / \mathbf{m}^{\mathbf{2}}\right)$ & $\begin{array}{c}\text { Frekuensi } \\
(\mathbf{n})\end{array}$ & $\begin{array}{c}\text { Persentase } \\
(\mathbf{\%})\end{array}$ \\
\hline Kurus $(<18,5)$ & 9 & 25,0 \\
Normal $(18,5-24,99)$ & 20 & 55,6 \\
Gemuk $(25-29,99)$ & 6 & 16,7 \\
Obese $(\geq 30)$ & 1 & 2,8 \\
\hline Total & 36 & 100,0 \\
\hline
\end{tabular}


Tabel 9. Distribusi Kebiasaan Merokok Responden di Industri Sawmill Tahun 2017

\begin{tabular}{lcc}
\hline Kebiasan Merokok & Frekuensi (n) & $\begin{array}{c}\text { Persentase } \\
(\%)\end{array}$ \\
\hline Perokok & 23 & 63,9 \\
Mantan Perokok & 3 & 8,3 \\
Bukan Perokok & 10 & 27,8 \\
\hline Total & 36 & 100,0 \\
\hline
\end{tabular}

Tabel 10. Distribusi Kebiasaan Menggunakan Alat Pelindung Pernapasan Responden di Industri Sawmill Tahun 2017

\begin{tabular}{lcc}
\hline $\begin{array}{c}\text { Kebiasaan } \\
\text { Menggunakan APP }\end{array}$ & Frekuensi (n) & $\begin{array}{c}\text { Persentase } \\
(\%)\end{array}$ \\
\hline Tidak Pernah & 17 & 47,2 \\
Sering & 8 & 22,2 \\
Selalu & 11 & 30,6 \\
\hline Total & 36 & 100,0 \\
\hline
\end{tabular}

perokok sebanyak $8,3 \%$ yang telah berhenti merokok selama 2,3 dan 5 tahun.

\section{Kebiasaan Menggunakan Alat Pelindung Pernapasan}

Berdasarkan Tabel 10 diketahui bahwa mayoritas pekerja di industri sawmill tidak pernah menggunakan alat pelindung pernapasan yakni sebesar $47,2 \%$.

\section{Distribusi Status Faal Paru berdasarkan Dosis Paparan dan Karakteristik Individu}

Berdasarkan Tabel 11 diketahui bahwa pekerja yang terpapar dosis debu $>5 \mathrm{mg} / \mathrm{m}^{3}$.tahun dan mengalami gangguan faal paru adalah sebanyak $64.7 \%$ lebih banyak dibanding pekerja yang yang terpapar dosis debu $<5 \mathrm{mg} / \mathrm{m}^{3}$.tahun yakni $42.1 \%$.

Pekerja yang berumur $>44$ tahun dan mengalami gangguan faal paru adalah sebanyak $60 \%$ lebih banyak dibanding pekerja yang berumur $\leq$ 44 tahun yakni 47,6\%.Pekerja dengan status indeks massa tubuh obes dan mengalami gangguan faal paru adalah sebanyak 100\% lebih banyak dibanding pekerja yang gemuk sebanyak $50,0 \%$ dan normal sebanyak $60 \%$ dan kurus sebanyak $33,3 \%$.

Pekerja yang merokok mengalami dan gangguan faal paru adalah sebanyak $69,6 \%$ lebih banyak dibanding pekerja yang tidak merokok yakni sebanyak $30 \%$. Pekerja yang tidak pernah
Tabel 11. Distribusi Status Faal Paru Berdasarkan Dosis Paparan dan Karakteristik Pekerja di Industri Sawmill Tahun 2017

\begin{tabular}{lcccc}
\hline \multirow{2}{*}{ Variabel } & \multicolumn{4}{c}{ Status Faal Paru } \\
\cline { 2 - 5 } & \multicolumn{2}{c}{ Normal } & \multicolumn{2}{c}{ Normal } \\
\cline { 2 - 5 } & $\mathbf{n}$ & $\mathbf{\%}$ & $\mathbf{n}$ & $\mathbf{\%}$ \\
\hline Dosis paparan & & & & \\
$\quad>5 \mathrm{mg} / \mathrm{m}^{3}$.tahun & 11 & 64,7 & 6 & 35,3 \\
$\leq 5 \mathrm{mg} / \mathrm{m}^{3}$.tahun & 8 & 42,1 & 11 & 57,9 \\
Umur & & & & \\
$>44$ tahun & 9 & 60,0 & 6 & 40,0 \\
$\quad \leq 44$ tahun & 10 & 47,6 & 11 & 52,4 \\
Status IMT & & & & \\
$\quad$ Obes & 1 & 100,0 & 0 & 0,0 \\
$\quad$ Gemuk & 3 & 50,0 & 3 & 50,0 \\
$\quad$ Normal & 12 & 60,0 & 8 & 40,0 \\
$\quad$ Kurus & 3 & 33,3 & 6 & 66,7 \\
Kebiasaan Merokok & & & & \\
$\quad$ Perokok & 16 & 69,6 & 7 & 30,4 \\
$\quad$ Mantan perokok & 0 & 0,0 & 3 & 100,0 \\
$\quad$ Bukan perokok & 3 & 30,0 & 7 & 70,0 \\
Kebiasaan & & & & \\
Menggunakan APD & & & & \\
$\quad$ Tidak pernah & 13 & 76,5 & 4 & 23,5 \\
$\quad$ Sering & 3 & 37,5 & 5 & 62,5 \\
$\quad$ Selalu & 3 & 27,3 & 8 & 72,7 \\
\hline
\end{tabular}

menggunakan alat pelindung pernapasan dan mengalami gangguan faal paru adalah sebanyak $76,5 \%$ lebih banyak dibanding pekerja yang sering menggunakan alat pelindung pernapasan (3-4 kali seminggu) yakni sebanyak $37,5 \%$ dan yang selalu menggunakan alat pelindung pernapasan yakni sebanyak $27,3 \%$. Jika dilihat dari persentase antara status faal paru dengan dosis paparan dan karakteristik individu, perbedaannya tidak terlalu terlihat, namun menunjukkan adanya kecenderungan.

\section{PEMBAHASAN}

Hasil pengukuran kadar debu Rata-rata selama 8 jam di industri sawmill adalah $1,59 \mathrm{mg} /$ $\mathrm{m}^{3}$, sedangkan nilai ambang batas yang telah ditetapkan oleh Peraturan Menteri Tenaga Kerja dan Transmigrasi (PERMENAKER) Nomor PER.13/MEN/X/2011 tahun 2011 tentang nilai ambang batas faktor fisika dan kimia di tempat kerja adalah sebesar $1 \mathrm{mg} / \mathrm{m}^{3}$ untuk kayu keras dan $5 \mathrm{mg} / \mathrm{m}^{3}$ untuk kayu lunak, sementara nilai ambang 
batas yang ditetapkan oleh American Conference of Governmental Industrial Hygienist (ACGIH) tentang TLV dan BEI's adalah sebesar $0,5 \mathrm{mg} / \mathrm{m}^{3}$ untuk western redwood dan $1 \mathrm{mg} / \mathrm{m}^{3}$ untuk semua jenis kayu. Jenis kayu yang digunakan di industri sawmill kota Gresik adalah merbau, keruing, kamper, meranti dan bengkirai sehingga masuk ke dalam kategori kayu keras. Kayu keras adalah jenis tumbuhan berbiji tertutup, sedangkan kayu lunak adalah jenis tumbuhan berbiji terbuka seperti jenis konifer.

Berdasarkan hasil pengukuran yang telah dilakukan maka, kadar debu Rata-rata selama 8 jam dalam sehari melebihi nilai ambang batas yang telah ditetapkan. Berdasarkan lampiran yang terdapat dalam American Conference of Governmental Industrial Hygienist (ACGIH, 2005) tentang TLV dan BEI's, paparan semua jenis debu kayu dapat mengakibatkan gangguan pada fungsi paru. Jika pekerja yang bekerja terpapar debu kayu terus menerus pada kadar melebihi nilai ambang batas yang telah ditetapkan, maka berisiko mengalami gangguan fungsi paru.

Kadar debu di industri sawmill dapat diturunkan di bawah nilai ambang batas melalui tindakan pengendalian, sehingga risiko gangguan fungsi paru pekerja juga dapat turun. Menurut Soeripto (2008), pada prinsipnya pengendalian yang dilakukan pertama kali adalah pengendalian secara teknis yakni dengan mengurangi atau membatasi jumlah partikel debu yang ada di lingkungan kerja. Pengendalian secara teknis terhadap kontaminan debu adalah dengan memasang sistem ventilasi keluar setempat (local exhaust ventilation), namun industri sawmill belum menggunakan local exhaust ventilation di area kerja untuk menurunkan kadar debu. Upaya pengendalian yang telah dilakukan oleh industri sawmill adalah dengan menyediakan masker sekali pakai untuk para pekerja, namun upaya tersebut merupakan upaya yang terakhir dilakukan jika pengendalian yang pertama tidak dapat dilakukan, selain itu masker tersebut kurang sesuai dengan peruntukannya dan masih banyak pekerja yang tidak menggunakan masker ataupun hanya menggunakan kaos sebagai pelindung saluran pernapasan. Meskipun industri sawmill telah melakukan beberapa pengendalian terhadap paparan debu kayu untuk para pekerja, namun belum dilakukan upaya untuk menurunkan kadar debu.

Pemeriksaan spirometri dilakukan untuk mengetahui kondisi faal paru pekerja. Hasil pemeriksaan faal paru pekerja di industri sawmill menunjukkan bahwa dari 36 pekerja, terdapat $52,8 \%$ pekerja mengalami gangguan faal paru dan $47,2 \%$ pekerja memiliki faal paru normal. Dari 19 orang $(52,85 \%)$ yang mengalami gangguan faal paru, terdapat $42,1 \%$ pekerja yang mengalami gangguan restriksi, $10,5 \%$ pekerja mengalami gangguan obstruksi dan $47,4 \%$ pekerja mengalami gangguan campuran. Derajat gangguan faal paru pekerja yakni sebesar $42,1 \%$ pekerja mengalami gangguan restriksi ringan dan sebesar $10,5 \%$ pekerja mengalami gangguan obstruksi ringan.

Gangguan restriksi merupakan gangguan faal paru dikarenakan adanya hambatan pada pengembangan paru yang ditandai dengan penurunan nilai FVC. Gangguan obstruksi adalah terjadinya gangguan faal paru karena terdapat hambatan aliran yang ditandai dengan penurunan $\mathrm{FEV}_{1}$, sedangkan jika terjadi gangguan obstruksi dan restriksi maka termasuk pada gangguan campuran. Pekerja yang mengalami gangguan restriksi ringan sebanyak $42,1 \%$, obstruksi ringan sebanyak $10,5 \%$. Dari data tersebut diketahui bahwa pekerja di industri sawmill mengalami gangguan restriksi dan obstruksi, selain itu data menunjukkan jika gangguan restriksi lebih banyak dialami daripada gangguan obstruksi.

Debu kayu merupakan jenis debu yang bersifat non fibrogenik dan tidak menimbulkan reaksi fibrosis pada jaringan paru, inhalasi debu kerja yang non fibrogenik hanya akan mengakibatkan bertambahnya jaringan ikat paru dalam jumlah yang sangat sedikit (Harrianto, 2010). Hasil penelitian ini menunjukkan bahwa pekerja di industri sawmill lebih banyak yang mengalami gangguan restriksi, sama halnya dengan hasil penelitian yang dilakukan oleh penelitian Ma'rufi (2016) yang menunjukkan bahwa sebanyak 96 pekerja perajin mebel kayu $(100 \%)$ mengalami gangguan restriksi dan 24 orang (25\%) pekerja mengalami gangguan obstruksi.

Penelitian Suryani, dkk (2005) juga menunjukkan bahwa sebanyak 12 orang $(17,1 \%)$ pekerja di mengalami gangguan restriksi dan sebanyak 3 orang $(4,3 \%)$ mengalami gangguan obstruksi. Penelitian Irjayanti, dkk (2012) yang menggunakan metode pengukuran debu dengan kadar debu terhirup (respirable) di 11 mebel kayu Jayapura, menunjukkan bahwa sebanyak 23 orang $(42,5 \%)$ mengalami gangguan restriksi, sebanyak 5 orang $(12,5 \%)$ mengalami gangguan restriksi sedang dan 18 orang (45\%) mengalami restriksi ringan. Hasil penelitian yang dilakukan di negara Cameroon, juga menunjukkan bahwa pada pekerja yang bekerja di industri kayu sektor informal, terdapat sebanyak 34 orang $(17,5 \%)$ mengalami gangguan restriksi 
dan sebanyak 12 orang $(6,2 \%)$ mengalami gangguan obstruksi (Francis, dkk, 2015). Hal ini menunjukkan bahwa pada hasil penelitian ini tidak berbeda dengan hasil penelitian yang lain.

Terjadinya gangguan restriksi akibat penurunan volume paru yang abnormal dapat disebabkan oleh perubahan pada parenkim paru, pleura, dinding paru atau melemahnya otot (Altalag, dkk., 2009). Gangguan restriksi tersebut berhubungan dengan menurunnya kekuatan fisik pada orang yang lebih tua serta dapat terjadi pada orang memiliki status indeks massa tubuh tinggi akibat meluasnya jaringan ekstra adiposa (Kurth, 2015). Semakin tua umur seseorang semakin terjadi perubahan pada jalan napas dan parenkim paru (Rosenthal, dkk., 2012). Gangguan faal paru pada pekerja di industri sawmill selain disebabkan oleh debu, dapat disebabkan oleh faktor bukan dari pekerjaan seperti umur, status indeks massa tubuh, gangguan pada pernapasan dan kebiasaan merokok (Aw, dkk., 2007).

Nilai rata-rata FVC pekerja di industri sawmill adalah sebesar $78,33 \%$ predictive, sehingga berada di bawah nilai $80 \%$ predictive, sedangkan nilai rata $\mathrm{FEV}_{1}$ sebesar $85,67 \%$ predictive, sehingga masih berada diatas nilai $80 \%$ predictive tetapi mendekati batas minimal. Jika dilihat dari rata-rata nilai $\mathrm{FEV}_{1}$ pada pekerja yang mengalami obstruksi $\left(\mathrm{FEV}_{1}<80 \%\right.$ predictive), maka didapatkan rata-rata nilai $\mathrm{FEV}_{1}$ sebesar $70,7 \%$ predictive dengan nilai minimum sebesar $63 \%$ predictive, sedangkan rata-rata nilai FVC pada pekerja yang mengalami gangguan restriksi (FVC $<80 \%$ predictive) adalah sebesar $68,6 \%$ predictive dengan nilai terendah adalah $56 \%$ predictive. Bagi pekerja yang memiliki faal paru normal, maka ke depannya dapat mengalami gangguan bila terpapar debu terus menerus, sedangkan bagi pekerja yang mengalami gangguan faal paru bila terpapar debu terus menerus dan seiring bertambah umur, dapat bertambah derajat keparahannya dari obstruksi maupun restriksi ringan menjadi sedang. Terjadinya gangguan faal paru di industri sawmill dapat diakibatkan oleh dosis paparan debu kayu yang diterima pekerja maupun faktor lain seperti umur pekerja, status indeks massa tubuh, kebiasaan merokok serta kebiasaan menggunakan alat pelindung pernapasan.

Risiko kesehatan pekerja yang bekerja di tempat yang berdebu dapat tergantung pada tingkat kadar debu dan lama kerja, atau yang dinamakan dengan dosis (Lu, 2006). Semakin tinggi dosis paparan, maka pekerja semakin berisiko memiliki gangguan kesehatan. Hasil penelitian ini menunjukkan pekerja yang terpapar dosis $>5 \mathrm{mg} / \mathrm{m}^{3}$.tahun mengalami gangguan faal paru lebih banyak yakni sebanyak 11 orang $(64,7 \%)$ dari pekerja yang terpapar dosis $\leq 5 \mathrm{mg} / \mathrm{m}^{3}$.tahunyakni sebanyak 8 orang $(42,1 \%)$. Hal ini menunjukkan bahwa adanya kecenderungan mengalami gangguan faal paru pada pekerja yang terpapar dosis $>5 \mathrm{mg} / \mathrm{m}^{3}$.tahun. Penelitian yang dilakukan oleh Chen, dkk (1997) pada pekerja karung goni juga menunjukkan bahwa pekerja yang terpapar pada dosis $<60 \mathrm{mg} / \mathrm{m}^{3}$.tahun, $60-180$ $\mathrm{mg} / \mathrm{m}^{3}$.tahun dan $>180 \mathrm{mg} / \mathrm{m}^{3} /$ tahun mengalami gangguan faal paru sebesar $11,1 \%, 21,1 \%$ dan $28,6 \%$. Penelitian yang dilakukan oleh Qian, dkk (2016) juga menunjukkan adanya perbedaan persentase pekerja yang mengalami gangguan faal paru pada dosis paparan $1.000 \mathrm{mg} / \mathrm{m} 3$.tahun yakni sebesar $44,4 \%$ dan terus meningkat sampai 1.700 $\mathrm{mg} / \mathrm{m} 3$.tahun yakni sebesar $80 \%$. Selain dosis paparan, faktor lain seperti umur, status indeks massa tubuh (IMT), kebiasaan merokok dan kebiasaan menggunakan alat pelindung pernapasan juga dapat memengaruhi faal paru pekerja.

Fungsi paru dapat mengalami penurunan sesuai bertambahnya umur. Paru-paru orang yang lebih tua juga lebih lama terkena paparan rokok, infeksi pernapasan, polusi udara dan paparan di tempat kerja seperti debu dan fume. Semakin bertambahnya umur, terjadi perubahan pada jalan napas maupun parenkim paru. Pada jalan napas, dapat terjadi hipertrofi saluran mukus. Selain itu, pada parenkim paru, saluran pernapasan bronkiolus dan alveolar mengalami pelebaran yang dimulai pada usia 30 atau 40 tahun dan perbedaannya sangat mencolok setelah usia 60 tahun. Proporsi udara di alveolar menurun karena volume udara di saluran alveolar meningkat. Jarak antara dinding alveolar meningkat, sementara rasio permukaan/volume paru-paru menurun. Sebagai hasil perubahan tersebut, luas permukaan alveolar menurun sekitar $15 \%$ pada usia 70 tahun (Rosenthal, dkk., 2011). Penelitian ini menunjukkan bahwa sebanyak 9 orang $(60 \%)$ pekerja yang berumur $>44$ tahun mengalami gangguan faal paru. Hal ini menunjukkan bahwa ada kecenderungan mengalami gangguan faal paru pada pekerja yang berumur lebih tua. Pada penelitian Febrianto, dkk (2015) menunjukkan bahwa umur memengaruhi faal paru dikarenakan secara fisiologi kemampuan organ-organ di dalam tubuh mengalami penurunan termasuk faal paru.

Hasil penelitian ini juga diketahui rentang umur pekerja yang bekerja di UD. Sinar Abadi adalah mulai dari 17 hingga 62 tahun, sehingga 
terdapat pekerja yang bekerja di bawah umur 18 tahun. Menurut Undang-Undang Republik Indonesia Nomor 13 tahun 2003 pasal 68, pengusaha dilarang mempekerjakan anak, sedangkan pada pasal 1 menjelaskan bahwa anak adalah setiap orang yang berumur di bawah 18 (delapan belas) tahun.

Peranan lemak yang berlebihan pada paru-paru merupakan permasalahan kesehatan masyarakat yang berhubungan dengan obesitas karena keterkaitannya dengan kesulitan bernapas (Gibney, dkk, 2009). Dampak obesitas pada pernapasan adalah kesulitan bernapas sebagai akibat dari peningkatan kerja otot respirasi yang diperlukan untuk mengatasi hambatan dalam bernapas. Terdapat jaringan ekstra adiposa pada dinding dada dan rongga abdominal, sehingga menekan toraks, menurunkan kemampuan diafragma untuk turun dan menurunkan kemampuan dinding dada dan paru-paru untuk mengembang, serta peningkatan elastik recoil, sehingga mengakibatkan penurunan volume paru-paru (Costa, dkk., 2008).

Data mengenai tinggi badan dan berat badan pekerja dapat digunakan untuk mengetahui status indeks massa tubuh pekerja. Pekerja yang obes dan mengalami gangguan faal paru adalah 1 orang $(100 \%)$. Pekerja yang gemuk dan mengalami gangguan faal paru adalah 3 orang $(50 \%)$ dan, justru pada pekerja yang kurus, sebanyak 6 orang $(66,7 \%)$ memiliki faal paru normal dan hanya 3 orang yang memiliki gangguan faal paru $(33,3 \%)$. Hal ini menunjukkan bahwa orang yang kurus cenderung memiliki faal paru normal dan semakin besar indeks massa tubuh seseorang, maka ada kecenderungan untuk mengalami gangguan faal paru. Penelitian yang dilakukan oleh Satriyani, dkk (2015) pada mahasiswa Fakultas Kedokteran Universitas Sam Ratulangi Manado menunjukkan bahwa sebanyak 13 orang $(40,6 \%)$ yang mengalami obesitas I dan 19 orang $(59,4 \%)$ mengalami obesitas II, sebanyak 7 orang $(21,9 \%)$ mengalami gangguan restriksi. Selain itu, pada penelitian Fung, dkk (1990) menunjukkan bahwa ada hubungan yang positif antara status indeks massa tubuh dan fungsi paru pada anak perempuan yang memiliki indeks massa tubuh normal dibandingkan dengan gemuk. Meskipun, pada penelitian ini pekerja yang memiliki status indeks massa tubuh normal dan mengalami gangguan faal paru adalah sebanyak 12 orang $(60 \%)$, namun tidak terlalu jauh perbedaannya dengan pekerja yang memiliki indeks massa tubuh gemuk dan mengalami gangguan faal paru yakni sebanyak 3 orang $(50 \%)$.
Merokok dapat merusak silia di lapisan epitel saluran udara, debris dan mukus tidak dapat dibuang dari paru- paru. sehingga tidak bisa melakukan mekanisme pembersihan. Kandungan bahan dalam rokok dapat menyebabkan sel imun pernapasan melepas molekul pertahanan, yakni enzim yang dikeluarkan untuk merusak jaringan alveolar. Merokok merupakan penyebab utama penyakit emfisema, bronkitis kronis dan kanker paru. Banyaknya rokok per hari dan lamanya merokok merupakan faktor determinan terjadinya kanker paru (Whittemore, 2004). Berdasarkan hasil penelitian ini diketahui bahwa pekerja yang merupakan perokok dan mengalami gangguan faal paru adalah sebanyak 16 orang $(69,6 \%)$, sedangkan orang yang bukan perokok dan mengalami gangguan faal paru hanya 3 orang (30\%). Dari pekerja yang merupakan mantan perokok, tidak ada yang mengalami gangguan faal paru. Pekerja yang berhenti merokok tersebut ada yang telah berhenti merokok selama 2 tahun, 3 tahun dan 5 tahun. Hal ini menunjukkan bahwa ada kecenderungan mengalami gangguan faal paru pada pekerja yang merokok.

Tubuh memulai perbaikan segera setelah berhenti merokok, tetapi beberapa organ mungkin tidak dapat sembuh secara sempurna, tergantung berapa lama merokok. Umumnya, kemungkinan besar risiko penyakit pada orang yang berhenti merokok untuk turun adalah setelah 2 sampai 3 tahun. Butuh lebih dari 10 tahun untuk orang yang berhenti merokok agar memiliki risiko yang sama dengan orang yang tidak pernah merokok. Risiko infark miokardial menurun hampir sepertiga setelah satu tahun berhenti merokok dan mencapai level yang sama dengan orang yang tidak merokok setelah 3 sampai 4 tahun (Herrick, dkk., 2009). Penelitian Frankdkk (2006), mengenai gejala pernapasan dan kemungkinan asma menunjukkan bahwa perokok memiliki prevalensi kemungkinan mengalami asma lebih tinggi dibandingkan dengan bukan perokok dengan OR 1,59, dan dibandingkan dengan mantan perokok dengan OR 1,79, serta tidak ada perbedaan antara bukan perokok dan mantan perokok dengan OR 1, sehingga berhenti merokok memiliki dampak yang baik terhadap prevalensi gejala pernapasan.

Pekerja yang terbiasa menggunakan alat pelindung pernapasan, maka saluran pernapasannya akan terlindung dari paparan debu (Soeripto, 2008). Sehingga orang yang tidak pernah menggunakan alat pelindung pernapasan lebih berisiko mengalami gangguan faal paru akibat terpapar debu terus 
menerus. Penelitian ini menunjukkan bahwa pekerja yang tidak pernah menggunakan alat pelindung pernapasan dan gangguan faal paru adalah sebanyak 13 orang $(76,5 \%)$ paling banyak bila dibandingkan dengan pekerja yang sering ataupun selalu menggunakan alat pelindung pernapasan. Hal ini menunjukkan bahwa pekerja yang tidak pernah menggunakan alat pelindung pernapasan cenderung mengalami gangguan faal paru.

\section{SIMPULAN}

Hasil pengukuran kadar debu di industri sawmill selama 8 jam kerja adalah sebesar 1,59 $\mathrm{mg} / \mathrm{m}^{3}$, sedangkan hasil pengukuran faal paru menunjukkan bahwa dari 36 pekerja, terdapat $52,8 \%$ mengalami gangguan faal paru dan 47,2\% memiliki faal paru normal. Berdasarkan jenis gangguannya, terdapat $47,4 \%$ mengalami gangguan campuran, 10,5\% mengalami gangguan obstruksi dan $42,1 \%$ mengalami gangguan restriksi, sedangkan berdasarkan derajat gangguan nya, terdapat $42,1 \%$ mengalami gangguan restriksi ringan, 10,5\% mengalami obstruksi ringan. Pekerja yang mengalami gangguan faal paru cenderung dialami oleh pekerja yang berumur lebih tua, memiliki status indeks massa tubuh lebih tinggi, memiliki gangguan pada pernapasan, memiliki kebiasaan merokok, serta tidak pernah menggunakan alat pelindung pernapasan.

\section{DAFTAR PUSTAKA}

American Conference of Governmental Industrial Hygienist (ACGIH),, 2005. Threshold Limit Values and Biological Exposure Index. Cincinnati: American Conference of Govermental Industrial Higienist

American Thoracic Society (ATS)., 2005. Standardization of Spirometry. European Respiratory Journal. [e-Journal] 26: pp. 319338

Aw, T. C., Gardiner, K., Harrington, J. M., 2007. Occupational Health. $5^{\text {th }} \mathrm{ed}$, [e-book] USA: Blackwell Publiching

Chen, J., Lou, J., Guo, X., Zhou, C., 1997. Pulmonary Function in Jute Dust-Exposed Workers: A DoseResponse Relationship. Journal of Occupational Health, [e-Journal] 39 pp: 313-318

Costa D., Barbalho, M.C., Miguel, G.P.S., Forti,
E.M.P., Azevedo, J.L.M.C., 2008. The Impact of Obesity on Pulmonary Function in Adult Women. Journal Clinics, [e-Journal] 63(6): pp. 719-724

Ennin, I. E., Adzaku, F. K., Dodoo, D., Adukpo, S., Boasiako, C. A., Antwi, D. A., 2015. A Study of Lung Function Indices of Woodworkers at the Accra Timber Market in Ghana. Donnish Journal, [e-Journal] 2(8) : pp. 120-124

Febrianto, A. A., Sujoso, A. D. P., Hartanti, R. I., 2015. Hubungan antara Karakteristik Individu, Paparan Debu Asap Las (Welding Fume) dan Gas Karbon Monoksida (CO) dengan Gangguan Faal Paru Pada Pekerja Bengkel Las (Studi di Kelurahan Ngagel Kecamatan Wonokromo Surabaya). Jurnal Pustaka Kesehatan, [e-Journal] 3(3): pp. 15-521

Francis, N.D.E., Mbatohou, H., Nebo, J., Djomo, A., Tsafack, P., Brouwer, C.D., 2015. Respiratory Symptoms and Pulmonary Function Test Among Informal Sector Workers Exposed to Wood Dust in Douala, Cameroon. Journal Allergy and Therapy, [e-Journal] 6(6): pp. 1-4

Frank, P., Morris, J., Hazell, M., Linehan, M., Frank, T., 2006. Smoking, Respiratory Symptoms and Likely Asthma in Young People: Evidence From Postal Questionnaire Surveys in the Wythenshawe Community Asthma Project (WYACP). Journal BMC Pulmonary Medicine, [e-Journal] 6(10): pp. 1-5

Fung, K. P., Lau, S. P., Chow, O. K. W., lee, J., Wong, T. W., 1990. Effects of Overweight on Lung Function. Journal Archives of Disease in Childhood, [e-Journal] 65(5): pp. 512-515

Gibney, M.J., Margetts, M. M., Kearney, J. M., Arab, L., 2009. Gizi Kesehatan Masyarakat. Jakarta: EGC

Global Initiative for Chronic Obstructive Lung Disease (GOLD)., 2010. Spirometry for HealthCare Providers. USA: Global Initiative for Chronic Obstructive Lung Disease

Harrianto, R., 2010. Buku Ajar Kesehatan Kerja. Jakarta: EGC

Herrick, C., Herrick C., Mitchell M., 2010. 100 Questions and Answers About How to Quit Smoking, [e-book] Canada: Jones\& Barlett Learning

International Agency For Research On Cancer (IARC)., 2012. Arsenic, Metals, Fibres, and Dusts : A Review of Human Carcinogens. Lyon: International Agency For Research On Cancer Irjayanti, A., Nurjazuli, Suwondo, A., 2012. 
Hubungan Kadar Debu Terhirup (Respirable) dengan Kapasitas Vital paksa Paru pada Pekerja Mebel Kayu di Kota Jayapura. Jurnal Kesehatan Lingkungan Indonesia, [e-Journal] 11(2): pp. 182-186

Italag, A., Road, J., Wilcox, P., 2009. Pulmonary Function Tests in Clinical Practice,[e-Book] London: Springer

Kang, M. J., Oh, Y. O., Lee, J. C., Kim, M. J., Lee., M. G., Hyun, I. G., et al., 2003. Lung Matrix Metalloproteinase-9 Correlates with Cigarette Smoking and Obstruction of Airflow. Journal of Korean Medical Science, [e-Journal] 18(6): pp. 821-827

Kauppinen, T., Vincent, R., Liukkonen, T., Grzebyk, M., Kauppinen A, Welling, I., et al., 2006. Occupational Exposure to Inhalable Wood Dust in the Member States of the European Union. The Annals of Occupational Hygiene, [e-Journal] 50(6): pp. 549-561

Kurth, L., Hnizdo, E., 2015. Change in Prevalence of Restrictive Lung Impairment in the U.S. Population and Associated Risk Factors: the National Health and Nutrition Examination Survey (NHANES) 1988-1994 and 2007-2010. Journal Multidisciplinary Respiratory Medicine, [e-Journal] 10(7): pp. 1-9

Lu, F. C., 2006. Toksikologi Dasar: Asas, Organ Sasaran, dan Penilaian Risiko. Jakarta: Universitas Indonesia Press

Ma'rufi, I., 2016. Efek Pajanan Debu Kayu terhadap Gangguan Faal Paru. Jurnal Media Pharmaceutica Indonesiana, [e-Jurnal] 1(1): pp. 45-52

N.C Departement of Labor (NCDOL)., 2012. A Guide to Occupational Exposure to Wood, Wood Dust and Combustible Dust hazards. North Carolina: N.C. Department of Labor.

Occupational Safety and Health Administration (OSHA)., 2013. Spirometry Testing in Occupational Health Programs. Washington: Occupational Safety and Health Administration

Peraturan Menteri Tenaga Kerja dan Transmigrasi Nomor PER.13/MEN/X/2011 Tahun 2011 Tentang Nilai Ambang Batas Faktor Fisika dan Kimia di Tempat Kerja. Jakarta: Kementerian Tenaga Kerja dan Transmigrasi
Qian, Q.Z., Cao., X.K., Qian, Q.Q., Shen, F.H., Wang, Q., Liu, H.Y., Tong, J.W., 2016. Relationship of Cumulative Dust Exposure Dose and Cumulative Abnormal Rate of Pulmonary Function in Coal Mixture Workers. Kaohsiung Journal of Medical Sciences, [e-Journal] 32(1): pp. 44-49

Rosenthal R. A., Zenilman M. E., Katlic M. R., 2011. Principles and Practice of Geriatric Surgery, [ebook] New York: Springer Science+Bussiness Media

Satriyani, Pandelaki, K., Wongkar, M.C.P., 2015. Hubungan Obesitas dengan Faal Paru pada Mahasiswa Fakultas Kedokteran Universitas Sam Ratulangi Manado. Jurnal e-Clinic, [e-Jurnal] 3(1): pp. 113-117

Schlünssen, V., Schaumburg, I., Taudorf, E., Mikkelsen, A.B., Sigsgaard, T., 2002. Respiratory Symptomps and Lung Function among Danish Woodworkers. Journal of Occupation and Environment Medicine,[e-Journal] 44(1): pp. 82-98

Soeripto, M., 2008. Higiene Industri. Jakarta: Balai Penerbit Fakultas Kedokteran Universitas Indonesia

Suma'mur, P. K., 2009. Higiene Perusahaan dan Kesehatan Kerja. Jakarta: Gunung Agung

Suryani, M., Setiani, O., Nurjazuli., 2005. Analisis Faktor Risiko Paparan Debu Kayu Terhadap Gangguan Fungsi Paru pada Pekerja Industri Pengolahan Kayu PT. Surya Sindoro Sumbing Wood Industry Wonosobo. Jurnal Kesehatan Lingkungan Indonesia, [e-Jurnal] 4 (1): 17-22.

Suyono. J., 1995. Deteksi Dini Penyakit Akibat Kerja. Jakarta: EGC

Undang-Undang Republik Indonesia Nomor 13 Tahun 2003 tentang Ketenagakerjaan. Jakarta: Kementerian Ketenagakerjaan

Whittemore S., Cooley D. A., 2004. The Respiratory System, [e-book] New York : Infobase Publishing

World Health Occupational (WHO)., 2004. Global Database on Body Mass Index. Jenewa: World Health Organization 
